\title{
Gene Transfer for the Genetic Improvement of Perennial Fruit and Nut Crops
}

\author{
Ralph Scorza \\ U.S. Department of Agriculture, Agricultural Research Station, Appalachian Fruit Research Station, \\ 45 Wiltshire Road, Kearneysville, WV 25430
}

Perennial fruit and nut crops thus far have been relatively poor subjects for the application of gene isolation and gene transfer technologies. This is due to their long generation cycles, limited knowledge of their genetics and physiology, and the difficulty in regenerating many of these species in vitro. In spite of these difficulties, perennial fruits and nuts may represent the crops that, in the long term, could reap the greatest benefits from gene transfer technologies.

Long generation cycles and high levels of heterozygosity increase the time required to synthesize new stress-resistant cultivars with the qualities necessary for consumer acceptance. Genes for biotic and abiotic stress resistance in perennial fruit and nut crops are, in many cases, found in native or naturalized genotypes or in noncultivated species that generally produce poor quality fruits or nuts. For many fruit and nut crops, cultivars carrying novel traits cannot be developed within the span of a breeder's career. Juvenility periods range from 1 year for raspberry to 15 years for pecan (Sherman and Lyrene, 1983). Peach, a crop with a relatively short generation time of 3 to 4 years, has generally required 20 years from first fruiting to cultivar release.

The relatively large land areas necessary to grow segregating populations of tree crops to maturity adds considerable expense to breeding programs. High cost restricts the number of seedlings that can be grown and thus reduces the chances of encountering the rare combination of genes necessary to produce a superior cultivar. The production of some of the most economically important temperate and subtropical fruit crops relies on the use of a few cultivars. 'Bartlett' accounts for $76 \%$ of the commercial pear production in North America. 'Red Delicious' and 'Golden Delicious' make up $60 \%$ of the U.S. apple production and $47 \%$ of the European production. Wine quality is, in large part, based on the use of traditional cultivars. The cultivation of wine grapes in some European countries is tightly regulated, based on cultivar. Sour cherry production in the United States and Canada is based almost entirely on 'Montmorency'. These major fruit cultivars are broadly adapted, and a significant body of information exists concerning their production, storage, and marketing. New cultivars lack this information base, making their introduction and use difficult and slow. Flavors and textures of particular fruit cultivars, e.g., 'Bartlett' pear, are recognized and desired in the market. New cultivars without these particular characteristics may be at a disadvantage.

While breeders are aware of the problems of genetic vulnerability and strive to combine unrelated germplasm to produce new cultivars

I thank Richard Bell, Ann Callahan, and Peter Morgens for their stimulating and constructive discussions concerning topics covered in this paper. that will be accepted by the industry, it is clear that for some of our fruit crops, particularly in certain regions, the industry simply desires to have the same cultivars "improved." This aspect of genetic improvement can be approached through gene transfer.

\section{Problems and advantages for perennial fruit and nut crops}

Gene transfer has relied for the most part on the use of Agrobacterium tumefaciens. The practical application of this vector for gene transfer has depended on in vitro plant regeneration. Although regeneration has been reported for various perennial fruit and nut crops (Bajaj, 1988; Skirvin, 1981), efficient regeneration systems that would allow for the consistent production of many regenerated plants generally have not been developed. Regeneration efficiencies for many species are low and regeneration has been achieved with only a few cultivars or with seedlings. Low rates of regeneration negatively affect transformation frequency and thus the use of gene transfer techniques. Transformation of meristems through the use of A. tumefaciens or particle acceleration (McCabe et al., 1988; Ulian et al., 1988) could alleviate the problem of regeneration by allowing for the direct transformation of cultivars without the intervening regeneration process. Transformation of meristems most likely will result in the production of a high percentage of chimeral transgenic plants with sectors or layers of transformed and nontransformed tissues. Chimeras will present problems for breeders, but chimeras are not a new phenomenon (Pratt, 1983). Several important fruit cultivars are chimera1 (e.g., 'Max Red Bartlett' pear; 'Starking', 'Redspur', and 'Starkrimson' apples). Periclinal chimeras resulting from meristem transformation could present opportunities. Plants could be produced with transformed inner layers that would have transgenic roots and normal fruit. Transformation of the L-1 layer with an insecticidal protein could provide adequate insect resistance with only a relatively small proportion of the plant producing the foreign protein. The color of the fruit epidermis could be changed without affecting internal color.

While regeneration and transformation rates of fruit and nut crops may be low when compared with some herbaceous species, vegetative propagation offers an advantage in the use of those transgenic plants that are isolated. Once a fruit or nut cultivar is transformed and tested, it can be multiplied indefinitely through axillary bud proliferation in vitro, and in vivo through graftage or cuttage. The expression of the transferred gene would not be subject to recombination, which is a normal part of the sexual cycle. Transgenic isolates of a particular cultivar with different levels of expression of the transferred gene could be identified and propagated. This would, for example, allow growers to select a transgenic cultivar 
with a particular fruit color intensity, based on the level of expression of a transferred gene affecting fruit color.

While it is not yet possible to regenerate plants from clonal material of some fruit and nut species, plant regeneration from seedderived tissue has generally been more successful (Hammerschlag et al., 1985; Lane and Cossio, 1986; Mante et al., 1989; Tulecke, 1987; Tulecke and McGranahan, 1985). Since many fruit and nut cultivars are propagated by graftage onto seedling rootstocks, the development of transgenic rootstock seed sources offers an approach to the genetic improvement of rootstocks through gene transfer.

\section{Traits of interest}

Transgenic walnut, apple, and Rubus plants that express foreign reporter genes have been produced (Graham et al., 1990; James et al., 1989; McGranahan et al., 1988). These successes allow breeders to consider the traits that may be most feasibly manipulated through gene transfer. Few genes have been isolated from perennial fruit and nut crops. The use of genes isolated in other crops as probes for similar genes in fruit and nut crops will widen the scope of available genes. RFLP mapping (Beckmann and Soller, 1986; Helentjaris et al., 1985) and transposon tagging (Dash and Peterson, 1989) will also increase the availability of crop-specific genes. Currently, most genes being used for gene transfer have been isolated from microorganisms. The availability of genes dictates the traits that can be manipulated through gene transfer.

\section{Insect resistance}

The insecticidal protein gene isolated from Bacillus thurengensis is the most common gene being tested for insect resistance (Fischoff et al., 1987). While known initially to be effective against Lepidoptera, forms of the gene have been found that are effective against Diptera and Coleoptera (Aronson et al., 1986; Herrnstadt et al., 1986). The cowpea trypsin inhibitor isolated from cowpea has also been shown to inhibit insect feeding (Hilder et al., 1989). The effect of these genes to date has not been determined in fruit or nut crops. The safety and acceptance of fruit containing these foreign proteins will require study. Placing these genes under the regulation of promoters specific to leaves or stems would reduce levels of these proteins in fruit or eliminate them entirely if they are not transported into fruit. While such a strategy would make these genes ineffective against fruit pests, placing them under the regulation of promoters that were active only during early stages of fruit development may be feasible and may offer protection against important fruit pests. The potential for breakdown of resistance based on these proteins will require study.

\section{Disease resistance}

The major class of disease organisms currently receiving attention are viruses. The ability of viral coat protein genes, when expressed in plants, to reduce or eliminate viral replication and thus disease symptoms has opened up an exciting opportunity for controlling virus diseases of fruits and nuts (Nelson et al., 1988). Again, the safety of virus coat protein in foods will require research. Expression of these proteins in nonedible portions of the plant appears to be feasible. The use of transgenic rootstocks in the case of nepoviruses is a promising approach that would reduce or eliminate the presence of coat protein in the above-ground plant parts.

Lytic peptide genes, naturally occurring (cecropin) and synthetic, have been tested for their antibacterial effects in plants (Cetiner et al., 1989). It may be possible to use these genes for resistance to bacterial diseases of fruit crops, e.g., fire blight of apples and pears.

\section{Herbicide tolerance}

The first potentially useful gene transferred into plants was the gene for glyphosphate resistance isolated from Salmonella typhimurium (Fillatti et al., 1987). Transgenic herbaceous species and poplar have been shown to tolerate levels of this herbicide that are normally used to control weed species. The transfer of this gene into tree fruits and nuts may be particularly useful for trees in the nursery. Placing this gene under the regulation of promoters specific to nonfruiting portions of the plant, particularly leaves, would reduce or eliminate the presence of this enzyme in the fruit where it is unnecessary.

Genes for resistance to existing herbicides (Streber and Willmitzer, 1989) and to herbicides being developed will be isolated from microorganisms or herbaceous plants and may be available for use in fruit crops.

\section{Growth regulators}

Agrobacterium species naturally contain growth regulator genes on the Ti plasmid, which is transferred to the genome of the infected plant. Vectors may be "disarmed" (i.e., the genes that code for cytokinin and auxin production deleted from the Ti plasmid) or manipulated so that they contain only auxin or cytokinin genes, or the expression of these genes may be modified (Klee et al., 1987). "Shooty" mutants, which overproduce cytokinin, or "rooty" mutants, which overproduce auxin, may be used as vectors to control organogenesis in vitro (Smigocki and Owens, 1988). Such vectors then may be used to induce recalcitrant fruit or nut species to regenerate in vitro. The use of this technique to promote regeneration may require precise levels of gene expression. The levels of growth regulator produced by the vector that would induce one cultivar to regenerate may differ from the levels necessary to induce another cultivar to regenerate. Further, it would be desirable to induce the production of growth regulators only when necessary for regeneration. Continued growth regulator production in the regenerated plant could undesirably alter growth habit or productivity. Control of growth regulator production may be accomplished by using heat shock or other promoters whose function can be artificially manipulated.

The use of "rooty" A. tumefaciens strains or A. rhizogenes for rooting of difficult-to-root fruit and nut species both in vitro and in vivo offers promise (Patena et al., 1988; Strobel and Nachmias, 1985; Tepfer and Casse-Delbant, 1987).

The ORF 12 (rolC) locus on the Ri plasmid of A. rhizogenes, when transferred to tobacco, has produced dwarf plants with shortened corollas (Oono et al., 1987). This gene may present possibilities for manipulating tree growth.

\section{Fruit and nut quality traits}

Ultimately, consumer acceptance of the product drives the production of a particular fruit or nut cultivar. The manipulation of those characters that impact on consumer acceptance may offer some exciting possibilities for perennial fruits and nuts. The ability to manipulate fruit softening would have a major impact on the fruit industry. Fruit softening indirectly affects most characteristics that govern consumer acceptance. The inability to ship tree-ripe fruit of most species demands that fruit be picked before peak color, flavor, and aroma develops. While some characteristics, such as color, may develop during shipping and storage, many characteristics will never reach the levels that are attained in tree-ripe fruit. A common consumer complaint is that fruit are attractive but flavorless. Knowledge of the biochemistry of fruit softening and gene expression may one day lead to the production of transgenic cultivars in which softening can be delayed or controlled so that tree-ripened fruit with the characteristic flavors and aromas can be harvested, stored, and shipped, with softening induced in the market just before consumer purchase. Isolation of the polygalacturonase gene, antisense construction, and gene transfer have provided useful insights into the role of polygalacturonase in tomato fruit softening (Giovannoni et al., 1989). Gene expression during peach fruit development and softening is being studied with the objective of manipulating softening through gene transfer (Callahan et al., 1989, 1991).

The potential applications of gene transfer technologies to perennial fruit and nut crops are similar to those in herbaceous species. Insect and disease resistance, herbicide tolerance, and modification of vegetative and fruit characteristics are common goals for all plant species. Many fruit and nut crops suffer the disadvantage of being difficult to regenerate in vitro. It may be possible to overcome this problem by the development of transformation technologies that do not require regeneration. The dominance of a few major cultivars 
of many fruit and nut crops makes gene transfer a particularly attractive approach and one that could be highly important to industry if major cultivars were improved. Vegetative propagation of fruit and nut crops would potentially provide for a more rapid use of transgenic plants than would be possible if these crops were seed propagated, because expression of the transferred gene would not be modified by recombination, which is a normal part of the sexual cycle. Use of stable chimeras for producing transgenic and nontransgenic tissue layers may be possible for fruit and nut crops. Graftage could be used to separate transgenic rootstocks from nontransformed scions. While hybridization and selection will continue to offer a productive approach to the genetic improvement of perennial fruit and nut crops, it is apparent that gene transfer can provide an additional approach with unique advantages and disadvantages that must be carefully evaluated by the breeder as this technology is incorporated into fruit and nut breeding.

\section{Literature Cited}

Aronson, A.I., W. Beckman, and P. Dunn. 1986, Bacillus thuringiensis and related insect pathogens. Microbiol. Rev. 50:1-24.

Bajaj, Y.P.S. (ed.). 1988. Biotechnology in agriculture and forestry crops II. Springer-Verlag, New York.

Beckman, J.S. and M. Soller. 1986. Restriction fragment length polymorphisms in plant genetic improvement. Oxford Surveys Plant Mol. Cell Biol. 3:196-250.

Callahan, A., P. Morgens, and E. Walton. 1989. Isolation and in vitro translation of RNAs from developing peach fruit. HortScience 24:356358.

Callahan, A., R. Scorza, P. Morgens, S. Mante, J. Cordts, and R. Cohen. 1991. Breeding for cold hardiness: Searching for genes to improve fruit quality in cold-hardy peach germplasm. HortScience 26:522-526.

Cetiner, S., L.D. Baltran, J. M. Jaynes, and W.J. Blackmon. 1989. Utilizing novel lytic peptides for improving bacterial disease resistance in plants. ASHS 1989 Annu. Mtg., Tulsa, Okla., Prog. \& Abstr. p. 65.

Dash, S. and P.A. Peterson. 1989. Chromosome constructs for transposon tagging of desirable genes in different parts of the maize genome. Maydica 34:247-261.

Fillatti, J.J., B. Haissig, B. McCown, L. Comai, and D. Riemenschneider. 1987. Development of glyphosphate-tolerant Populus plants through expression of a mutant aroA gene from Salmonella typhimurium, p. 243249. In: J.W. Hanover and D.E. Keathley (eds.). Genetic manipulation of woody plants. Plenum Press, New York.

Fischoff, D.A., K.S. Bowdish, F.J. Perlak, P.G. Marrone, S.M. McCormick, J.G. Niedermeyer, D.A. Dean, K. Kusano-Kretzmer, E.J. Mayer, D.E. Rochester, S.G. Rogers, and R.T. Fraley. 1987. Insect tolerant transgenic tomato plants. Bio/Technology 5:807-813.

Giovannoni, J.J., D. DellaPenna, A.B. Bennett, and R.L. Fischer. 1989. Expression of a chimeric polygalacturonase gene in transgenic rin (ripening inhibitor) tomato fruit results in polynronide degradation but not fruit softening. Plant Cell 1:53-63.

Graham, J., R.J. McNicol, and A. Kumar. 1990. Use of the GUS gene as a selectable marker for Agrobacterium -mediated transformation of Rubus. Plant Cell, Tissue \& Organ Cult. 20:35-39.

Hammerschlag, F.A., G. Bauchan, and R. Scorza. 1985. Regeneration of peach plants from callus derived from immature embryos. Theor. Appl. Genet. 70:248-251.

Helentjaris, T., G. King, M. Slocum, C. Siedenstrang, and S. Wegman. 1985. Restriction fragment polymorphisms as probes for plant diversity and their development as tools for applied plant breeding. Plant Mol. Biol. 5:109-118.
Herrnstadt, C., G.G. Soares, E.R. Wilcox, and D.L. Edwards. 1986. A new strain of Bacillus thuringiensis with activity against Coleopteran insects. Bio/Technology 4:305-308.

Hilder, V.A., A.M.R. Gatehouse, and D. Boulter. 1989. Potential for exploiting plant genes to genetically engineer insect resistance, exemplified by the cowpea trypsin inhibitor gene. Pesticide Sci. 27:165-171.

James, D.J., A.J. Passey, D.J. Barbara, and M. Bevan. 1989. Genetic transformation of apple (Malus pumila Mill.) using a disarmed Ti-binary vector. Plant Cell Rpt. 7:658-661.

Klee, H.J., R.B. Horsch, M.A. Hinchee, M.B. Hein, and N.L. Hoffmann 1987. The effects of overproduction of two Agrobacterium tumefaciens T-DNA auxin biosynthetic products in transgenic petunia plants. Genes \& Dev. 1:86-96.

Lane, D.W. and F. Cossio. 1986. Adventitious shoots from cotyledons of immature cherry and apricot embryos. Can.J. Plant Sci. 66:953-959.

Mante, S., R. Scorza, and J.M. Cordts. 1989. Plant regeneration from cotyledons of Prunus persica, Prunus domestica, and Prunus cerasus. Plant Cell, Tissue \& Organ Cult. 19:1-11.

McCabe, D.E., W.F. Swain, B.J. Martinell, and P. Christou. 1988. Stable transformation of soybean (Glycine max) by particle acceleration. Bio/ Technology 6:923-926.

McGranahan. G.H.. C.A. Leslie. S.L. Uratsu. L.A. Martin. and A.M. Dandekar. 1988. Agrobacterium -mediated transformation of walnut somatic embryos and regeneration of transgenic plants. Bio/Technology 6:800-804

Nelson, R.S., S.M. McCormick, X. Delannay, P. Dube, J. Layton, E.J. Anderson, M. Kaniewska, R.K. Proksch, R.B. Horsch, S.G. Rogers, R.T. Fraley, and R.N. Beachy. 1988. Virus tolerance, plant growth, and field performance of transgenic tomato plants expressing coat protein from tobacco mosaic virus. Bio/Technology 6:403-409.

Oono, Y., T. Handa, K. Kanaya, and H. Uchimiya. 1987. The TL-DNA gene of Ri plasmids responsible for dwarfness of tobacco plants. Jpn. J. Genet. 62:501-505.

Patena, L., E.G. Sutter, and A.M. Dandekar. 1988. Root induction by Agrobactetium rhizogenes in a difficult-to-root woody species, Acta Hort. 227:324-329

Pratt, C. 1983. Somatic selection and chimeras, p. 172-185. In: J.N. Moore and J. Janick (eds.). Methods in fruit breeding. Purdue University Press, West Lafayette, Ind

Sherman, W.B. and P.M. Lyrene. 1983. Handling seedling populations, p. 66-73. In: J.N. Moore and J. Janick (eds.). Methods in fruit breeding. Purdue University Press, West Lafayette, Ind.

Skirvin, R.M. 1981. Fruit crops, p. 51-139. In: B.V. Conger (ed.). Cloning agricultural plants via in vitro techniques CRC Press, Boca Raton, Fla.

Smigocki, A.C. and L.D. Owens. 1988. Cytokinin gene fused with a strong promoter enhances shoot organogenesis and zeatin levels in transformed plant cells. Proc. Natl. Acad. Sci. USA 85:5131-5135.

Streber, W.R. and L. Willmitzer. 1989. Transgenic tobacco plants expressing a bacterial detoxifying enzyme are resistant to 2,4-D. Bio/Technology 7:811-816.

Strobel, G.A. and A. Nachmias. 1985. Agrobacterium rhizogenes promotes the initial growth of bare root stock almond. J. Gen. Microbiol. 131:12451249.

Tepfer, M. and F. Casse-Delbart. 1987. Agrobacterium rhizogenes as a vector for transforming higher plants. Microbial. Sci. 4:24-28.

Tulecke, W. 1987. Somatic embryogenesis in woody perennials, p. 61-91. In: J.M. Bonga and D.J. Durzan (eds.). Cell and tissue culture in forestry. vol 2. Martinis Nijhoff, Boston."

Tulecke, W. and G.H. McGranahan. 1985. Somatic embryogenesis and plant regeneration from cotyledon tissue of walnut, Juglans regia L. Plant Sci. 40:53-67.

Ulian, E.C., R.H. Smith, J.H. Gould, and T.D. McKnight. 1988. Transformation of plants via the shoot apex. In Vitro Cell Devel. Biol. 24:951955. 